\title{
HYPERCALCAEMIA ASSOCIATED WITH NEONATAL SUBCUTANEOUS FAT NECROSIS
}

\author{
BY \\ DONALD BARLTROP* \\ From The Hospital for Sick Children, Great Ormond Street, London
}

(RECEIVED FOR PUBLICATION FEBRUARY 11, 1962)

Localized neonatal subcutaneous fat necrosis has been well recognized since the description of Fabyan (1907). Since then many case reports have been published: thus Masi and Brancolini (1956) collected 179 reported cases. Calcium deposition in affected tissues was described by Harrison and McNee (1926) and a raised serum calcium was reported in one of their cases. The association of this condition with a raised serum calcium and symptoms suggestive of idiopathic hypercalcaemia has since been described in two case reports (Clay, 1956; Martin and Steven, 1957). No explanation for this association has yet been offered. In this paper a further case of neonatal subcutaneous fat necrosis is described in which a raised serum calcium was found, together with the symptoms of hypercalcaemia. The significance of hypercalcaemia in subcutaneous fat necrosis is discussed.

\section{Case Report}

C.R., a male infant and an only child, was delivered by caesarean section on June 13,1958 , on account of breech presentation. The birth weight was $10 \mathrm{lb} .1 \mathrm{oz}$. $(4,563 \mathrm{~g}$.) and he was believed to be one month postmature. Pregnancy had been complicated by toxaemia, but the mother had not received vitamin supplements. Soon after birth it was noticed that the skin of his back was discoloured by an extensive red area surmounted by a central blue streak. He was a difficult feeder and he failed to gain weight. His failure to thrive was associated with intermittent vomiting, poor appetite and infrequent stools. He was breast fed for the first six weeks of life; from 6 to 8 weeks he had Ostermilk No. 1 ; from 8 to 12 weeks he had 'lactogen' and from 12 to 16 weeks National dried milk. All the milk preparations used contained approximately 100 i.u. vitamin D per oz. powder, and thus provided approximately 17 i.u. per reconstituted ounce. Ostermilk and National dried feeds were made up with one teaspoonful

* Present address: Paediatric Unit, St. Mary's Hospital Medical School, London W.2. of a proprietary glucose preparation ('glucodin') which contained vitamin D 250 i.u. per oz., calcium $103 \mathrm{mg}$. per oz. and phosphorus $66 \mathrm{mg}$. per oz. He was not given cod liver oil and he did not receive any other preparation containing vitamin $\mathrm{D}$. His total daily intake of vitamin $D$ was estimated to be within the range 400-700 i.u. per day.

He was admitted to The Hospital for Sick Children, Great Ormond Street, on October 21, 1958, aged 4 months, when he weighed $9 \mathrm{lb}$. $1 \frac{1}{4} \mathrm{oz}$. $(4,117 \mathrm{~g}$.). Hypercalcaemia was found and treatment was started.

Examination. The infant was small for his age but otherwise well; there was no hypotonia. Scattered plaques and nodules of thickened subcutaneous tissue were present which probably represented resolving areas of fat necrosis; these were most easily felt on the anterior and posterior surfaces of the chest wall and the anterior surfaces of both thighs. The overlying skin was normal and there was no residual colour change, the plaques had some superficial attachment to overlying skin of the anterior chest wall with a resultant peau d'orange. No cardiac murmur or other abnormality was detected.

Laboratory Data. Serum calcium $12 \cdot 1 \mathrm{mg} .100 \mathrm{ml}$. (EDTA/murexide method, normal range 8.9-10.5 mg./100 ml.; Wilkinson, 1957), blood urea $70 \mathrm{mg} . /$ $100 \mathrm{ml}$., erythrocyte sedimentation rate $27 \mathrm{~mm}$. in one hour, $\mathrm{Hb} 97 \%$, white blood cells $9,200 /$ c.mm. (neutrophils $70 \%$, lymphocytes $20 \%$, monocytes $10 \%$ ). Microscopical examination of centrifuged deposit of urine showed no abnormality, culture sterile, Sulkowitch slightly increased. In a 24-hour collection of urine there were: calcium $35 \mathrm{mg}$. and phosphorus $354 \mathrm{mg}$. Serum phosphorus $5.5 \mathrm{mg} . / 100 \mathrm{ml}$, alkaline phosphatase 21 King-Armstrong units $/ 100 \mathrm{ml}$., sodium $135 \mathrm{mEq} / \mathrm{l}$., potassium $5 \cdot 1 \mathrm{mEq} / 1$, bicarbonate $27 \mathrm{mEq} / \mathrm{l}$., chloride $101 \mathrm{mEq} / \mathrm{l}$., cholesterol $287 \mathrm{mg} . / 100 \mathrm{ml}$., drop protein $6.3 \mathrm{~g} . / 1$. Electrophoresis of plasma proteins: $\alpha_{1}$ and $\gamma$ globulins slightly increased.

Histology of Skin Biopsy. A localized lesion was present in the subcutaneous fat. There was degeneration and necrosis of fat cells; fat crystals were present, some 
of which were doubly refractile. There was no calcification. The histological picture was consistent with nodular subcutaneous fat necrosis.

Radiological Data. There was no evidence of calcification in the subcutaneous tissues. Lung fields and cardiac shadow were normal.

Clinical Course. After admission to hospital vomiting and constipation ceased, and he began to gain weight. The proprietary glucose was stopped on admission, but he continued to have National dried milk. The improvement was coincident with a fall in his serum calcium to normal levels (Fig. 1).

In order to test the hypothesis that failure to thrive and hypercalcaemia were dependent on an abnormal response to dietary vitamin $D$, a sensitivity test was carried out. This took place over a 10-day period (November 21, 1958, to November 30, 1958, inclusive) when 2,000 i.u. vitamin $D_{2}$ was added to his diet. A slight rise in serum calcium and serum alkaline phosphatase occurred and he did not gain weight during the period of the test. Weight gain was resumed when vitamin $\mathrm{D}_{2}$ was withdrawn (Fig. 2).

He was discharged home on a diet of National dried milk and the mother was advised to avoid any other preparations containing vitamin D. He was well when re-examined at 8 months, and his skin lesions had regressed so that only slight residual thickening was present. Two months later atrophy of the subcutaneous tissues overlying lesions in the triceps region was observed.

Some retardation of physical and mental development occurred. Thus, he did not sit up until 10 months old, his first tooth appeared at the age of 11 months and he spoke his first words at 13 months. Retardation of skeletal development was found in radiographs of the wrists and knees which, at the chronological age of 11 months, were consistent with a bone age of 3 to 6 months.

When finally seen at the age of 4 years he was a healthy child of normal physical and mental development; there was, however, some permanent loss of subcutaneous tissue of the proximal upper limbs over the triceps and deltoid muscles.

\section{Discussion}

Disordered calcium metabolism in neonatal subcutaneous fat necrosis has been known since the report of Harrison and McNee (1926) who described five cases in two of which scattered calcification had occurred. In one of their cases a serum calcium of $15 \mathrm{mg}$./100 ml. was present. In two of their cases the calcium and phosphorus content of affected subcutaneous tissues was found to be raised after death. A similar increase in the calcium content of affected fat was described by Kohnstam and Herbert (1927) who found that ether-extracted residues of affected tissues contained $0.66 \%$

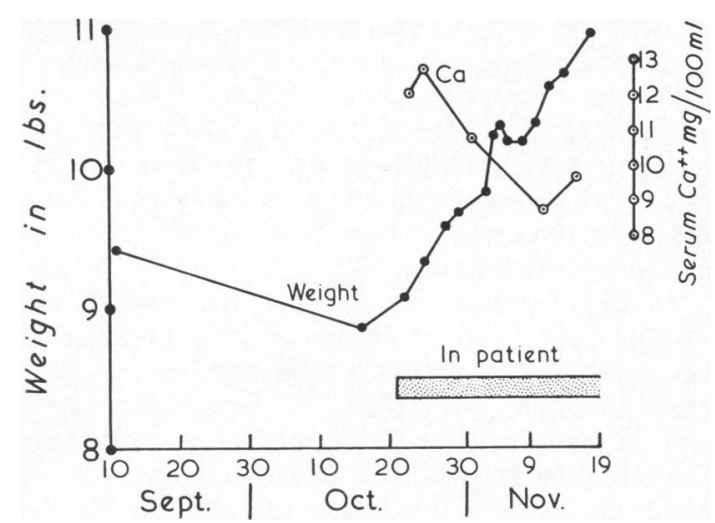

Fig. 1.-Simultaneous changes in weight and serum calcium.

calcium, compared with $0.07 \%$ in controls; these changes had occurred in the absence of microscopical evidence of calcification.

The clinical picture of hypercalcaemia in infancy was described by Lightwood (1952), and Payne (1952) presented the blood chemistry, but it was not until the single case reports of Clay (1956) and Martin and Steven (1957) that an association was reported with neonatal fat necrosis. It is of interest that in neither of these cases did symptoms referable to the hypercalcaemia appear until the fifth week after birth.

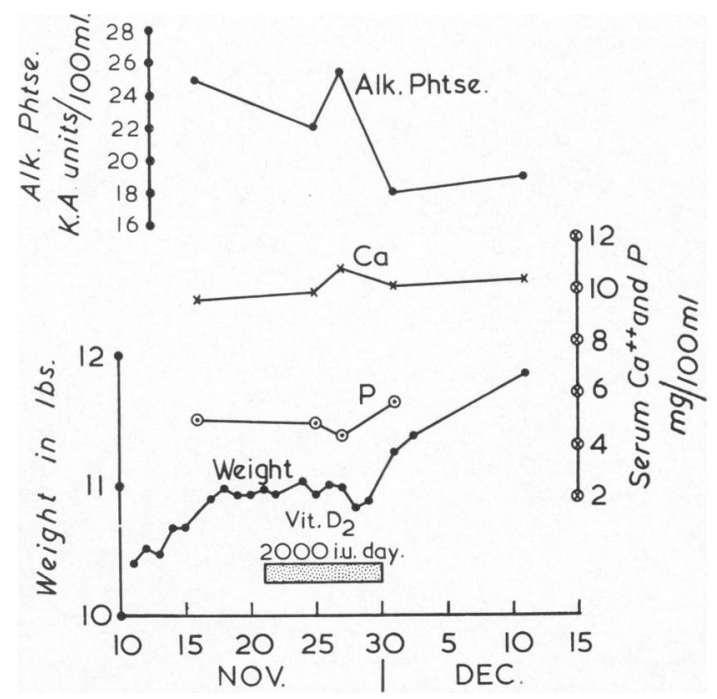

Fig. 2.-The effect of vitamin $D_{2}, 2,000$ i.u. daily, added to the diet, on weight, serum calcium, alkaline phosphatase and inorganic 
Hypersensitivity to vitamin $D$ has been suggested as the underlying mechanism of idiopathic hypercalcaemia (Bonham Carter, Dent, Fowler and Harper, 1955), and it seems to have been present in the case described in this paper. However, intolerance to vitamin $D$ does not prove that it is a causative rather than contributory factor in the genesis of high serum calcium states.

It seems likely that the release of large quantities of calcium during the resolution of areas of neonatal subcutaneous fat necrosis would also predispose to hypercalcaemia, particularly in the presence of a high intake of vitamin D or calcium, or stationary skeletal growth with diminished utilization of calcium. Perhaps the intake of vitamin $D$ and calcium should be restricted in cases of extensive subcutaneous fat necrosis, whether hypercalcaemia has or has not manifested.

\section{Summary}

A case of neonatal subcutaneous fat necrosis with evidence of hypercalcaemia is described in which evidence indicative of sensitivity to vitamin $D_{2}$ in a daily dosage of 2,000 i.u. over a 10-day period was present.
It is known that areas of fat necrosis may contain considerably more calcium than unaffected tissues; a ninefold increase has been reported. Reabsorption of this depot calcium during resolution may be a factor in the causation of associated hypercalcaemia.

I am grateful to Dr. Reginald Lightwood for his advice and criticism.

\section{REFERENCES}

Bonham Carter, R. E., Dent, C. E., Fowler, D. I. and Harper, C. M. (1955). Calcium metabolism in idiopathic hypercalcaemia of infancy with failure to thrive. Arch. Dis. Childh., 30, 399.

Clay, P. R. (1956). Idiopathic hypercalcaemia with subcutaneous calcium deposits following pseudosclerema. Proc. roy. Soc. Med., 49, 598.

Fabyan, M. (1907). Disseminated subcutaneous fat necrosis, occurring in an infant without other lesions. Bull. Johns Hopk. occurring in an

Harrison, G. A. and McNee, J. W. (1926). An investigation of sclerema neonatorum; with special reference to the chemistry of the subcutaneous tissues. Arch. Dis. Childh., 1, 63.

Kohnstam, G. L. S. and Herbert, F. K. (1927). Sclerema neonatorum and its relation to fat necrosis. ibid., $2,349$.

Lightwood, R. (1952). Idiopathic hypercalcaemia in infants with failure to thrive ibid., 27, 302.

Martin, M. M. and Steven, E. M. (1957). Subcutaneous fat necrosis of the newborn with calcification of the tissues. ibid., 32, 146.

Masi, A. and Brancolini, L. (1956). L'Adiponecrosi del tessuto sottocutaneo del neonato. Riv. Clin. pediat., 57, 362 .

Payne, W. W. (1952). The blood chemistry in idiopathic hypercalcaemia. Arch. Dis. Childh., 27, 302.

Wilkinson, R. H. (1957). A micro-method for serum calcium and serum magnesium. J. clin. Path., 10, 126. 